\title{
Effect Of Astaxanthin On Rat Brains Against Oxidative Stress Induced By Cadmium:Biochemical, Histopathological Evaluation
}

\author{
Hurrem Turan AKKOYUN ${ }^{1}$, Aydın Şükru BENGÜ², Aykut ULUCAN² ${ }^{2}$, Mahire Bayramoğlu AKKOYUN \\ Suat EKIN ${ }^{3}$, Yusuf TEMEL ${ }^{4}$, Mehmet ÇiFTÇi ${ }^{5}$
}

\begin{abstract}
Aim of this study is to evaluate protective impact_of Astaxanthin (AST) on rats with experimental brain injury induced with Cadmium (Cd). 32 male Wistar albino rats were divided into four groups as Control, Cadmium, Astaxanthin (AST), Cadmium (Cd)+Astaxanthin (AST). Rat brain tissues were obtained at the end of $30^{\text {th }}$ day. Malondialdehyde (MDA), glutathione (GSH) levels and superoxide dismutase (SOD) enzyme activities were measured in brain homogenates and histopathological examination was performed. MDA levels were improvement in cadmium administered group $(\mathrm{p}<0.01)$ as well as Cd+AST administered group $(\mathrm{p}<0.05)$ compared to control group. In addition a substantial reduction $\mathrm{Cd}+\mathrm{AST}$ group was observed compared to cadmium administered group $(\mathrm{p}<0.01)$. GSH level shows a decrease in $\mathrm{Cd}$ and $\mathrm{Cd}+\mathrm{AST}$ groups compared to control $(\mathrm{p}<0.05)$. SOD enzyme activity was found significantly lower in $\mathrm{Cd}$ and $\mathrm{Cd}+\mathrm{AST}$ groups compared to control $(\mathrm{p}<0.01)$. In addition, increase of SOD in $\mathrm{Cd}+\mathrm{AST}$ group compared to cadmium group was also found significant $(\mathrm{p}<0.05)$. Histopathological findings in the cerebral cortex and hippocampus were different between groups. In the control and AST administered groups, normal histological structure was observed in the brain, while severe lesions were seen in the $\mathrm{Cd}$ administered group and in the $\mathrm{Cd}+\mathrm{AST}$ group only mild degenerative lesions were observed.
\end{abstract}

As a result, elevated MDA level due to $\mathrm{Cd}$ administration was attenuated with AST administration. Decreased GSH level and SOD enzyme activity due to Cd administration was increased with AST administration. In addition, AST administration decreased histopathological lesions. Consequently, it is thought that AST may be used for protection against brain oxidative damage due to $\mathrm{Cd}$.

Keywords: Astaxanthin, cadmium, oxidative stress.

\section{Kadmiyum ile Oksidatif Strese Maruz Kalan Sıçanların Beyin Dokusunda Astaksantinin Etkisi;Biyokimyasal, Histopatolojik Değerlendirme}

ÖZET: Bu çalışmada, ratlarda kadmiyum (Cd), ile meydana gelen beyin hasarını önlemede astaksantinin (AST), koruyucu etkisinin değerlendirilmesi amaçlandı. 32 adet Winstar albino cinsi rat kontol, Kadmiyum (Cd), Astaksantin (AST), Kadmiyum (Cd)+Astaksantin (AST), olmak üzere dört gruba ayrıldı. 30. Günün sonunda rat beyin dokuları alınd. Beyin doku homojenatında malondialdehit (MDA), Glutatyon (GSH) seviyeleri ve süperoksitdismutaz (SOD) enzim aktivitesi ölçülerek, histopatolojik inceleme yapıldı. Beyin dokusu MDA, düzeyleri değerlendirildiğinde kontrol grubu ile kıyaslandığında Cd uygulaması yapılan grupta $(\mathrm{p}<0,01)$ ve yine $\mathrm{Cd}+\mathrm{AST}$ uygulanan grupta artış $(\mathrm{p}<0,05)$ olduğu belirlendi. Cd uygulaması yapılan gruba oranla $\mathrm{Cd}+\mathrm{AST}$ grubunda görülen azalmanın istatistiksel olarak önemli olduğu belirlenmişdir $(\mathrm{p}<0,01)$. GSH düzeyleri değerlendirildiğinde, $\mathrm{Cd}$ ve $\mathrm{Cd}+\mathrm{AST}$ grupları, kontrol grubu ile kıyaslandığında gruplar arasında istatistiksel olarak azalışın olduğu belirlendi $(p<0,05)$. SOD enzim aktivitesi değerlendirildiğinde ise $\mathrm{Cd}$ ve $\mathrm{Cd}+\mathrm{AST}$ gruplarında, kontrol grubuna kıyasla görülen azalışın $(\mathrm{p}<0,01)$ istatistiksel olarak önemli olduğu, $\mathrm{Cd}$ grubuna oranla, $\mathrm{Cd}+\mathrm{AST}$ uygulaması yapılan grupta SOD düzeyinde görülen artışın önemli olduğu belirlendi $(\mathrm{p}<0,05)$. Histopatalojik bulgular değerlendirildiğinde, Serebral korteks ve hipokampusta histopatolojik bulgular gruplar arasında farklılık gösterdi. Kontrol ve AST uygulanan gruplarda beyinde normal histolojik yapı gözlenirken, $\mathrm{Cd}$ uygulanan grupta ciddi lezyonlar görüldü. $\mathrm{Cd}+\mathrm{AST}$ grubunda hafif dejeneratif lezyonlar gözlendi. Sonuç olarak, Cd uygulamasına bağlı olarak artan MDA düzeyi, AST uygulması ile azaldı. Cd uygulaması ile azalan GSH düzeyi ve SOD enzim aktivitesi AST uygulaması ile arttı. Aynı zamanda AST uygulmasının histopatolojik lezyonları azalttığı gözlemlendi. Bundan dolayı, AST’nin Cd kaynaklı beyin oksidatif hasara karşı koruyucu olarak kullanılabileceği düşünülmektedir.

Anahtar Kelimeler: Astaksantin, Kadmiyum, Oksidatif stres.

Hurrem Turan AKKOYUN (0000-0002-4547-8003), Mahire Bayramoğlu AKKOYUN (0000-0016-2148-2003), Siirt University, Faculty of Veterinary Science, Siirt, Turkey

Aydın Sükrü BENGÜ (0000-0002-4158-5002), Aykut ULUCAN (0000-0013-3659-1002), Bingöl University, Department of Medical

Services and Technics, Vocational School of Health Services, Bingöl, Turkey

Suat EKIN (0000-0009-0296-0054), Van Yüzüncü Y1l Univesity, Faculty of Sciences, Van, Turkey

Yusuf TEMEL (0000-0156-0365-8024), Bingöl University, Solhan Health Services Vocational School, Bingöl, Turkey

Sorumlu yazar/Corresponding Author: Hurrem Turan AKKOYUN, turanakkoyun@hotmail.com

Mehmet ÇIFTÇI (0000-0005-0789-1008), Bingöl University, Faculty of Science, Bingöl, Turkey 


\section{INTRODUCTION}

Cadmium $(\mathrm{Cd})$ is a serious environmental pollutant that is very toxic to humans and animals, even in very small quantities (Singh et al., 2013).This metal is mainly used in agriculture, plastic stabilization, pigments and manufacturing of nickel-Cd batteries (Alaee et al.,2014).Cd can be found in certain drinks, fish, meat, milk, eggs, grains as well as in cigarette. Therefore, important sources of $\mathrm{Cd}$ intake are via food or cigarette (Yadav et al., 2010).Prolonged exposure to $\mathrm{Cd}$ causes toxic effects on cardiovascular, immune/ hematopoietic, skeletal, endocrine and reproductive systems and also kidneys, liver, brain and lungs (Fowler, 2009; Satarug et al., 2010).Cd accumulation causes serious toxic effects in brain (Karoui-Kharrat et al., 2017) as well as other neurological disorders such as hyperactivity, memory loss and learning toughness (Hart et al., 1989; Ciesielski et al.,2012; Szkup et al., 2012). Since brain has lower activity in enzymatic defense systems match_other organs it is indefensible oxidative stress (Shagirtha et al., 2016). Astaxanthin $\quad(3,30$-dihydroxy- $\beta, \quad \beta$-carotene-4,40dion) is one of the xanthophyll carotenoids found mostly in microalgae, fungi, complex plants, seafood, flamingos and quails (Hwang et al., 2017). Astaxanthin has some a wide range of biological activities such as including antioxidant,anti-inflammatory, anticancer and cardioprotective activities (Wu et al., 2012). Astaxanthin has a strong antioxidant property (Zuluaga et al.,2017). Therefore, In this study, it was aimed to investigate the protective effect of astaxanthin against rat brain injury exposed to cadmium in rats.

\section{MATERIAL AND METHODS}

\section{Experimental Animals}

32 (250 -300 gr) Male Wistar albino rat was obtained from Bingöl University Experimental Research Facility. Study was performed after acceptance of protocols by BUHADYEK (Date:04.04.2017/2017/04, Decision:04/02). 32 rats were divided into 4 groups including 8 animals per group. Control group $(n=8)$ : Oral isotonic saline was administered these animals. Cd group $(\mathrm{n}=8): 40 \mathrm{mg} / \mathrm{L}$ $\mathrm{CdCl}_{2}$ was administered as orally (Amara et al., 2011). AST group ( $\mathrm{n}=8)$ :AST was given at $20 \mathrm{mg} / \mathrm{kg}$ dose with gastric gauge (Otton et al., 2010). $\mathrm{Cd}+\mathrm{AST}(\mathrm{n}=8)$ : Rats were administered with $\mathrm{CdCI}_{2}: 40 \mathrm{mg} / \mathrm{L}$ day, orally and AST $20 \mathrm{mg} / \mathrm{kg} / \mathrm{day}$. At the end of $30^{\text {th }}$ day animals were anesthetized with i.p. $60 \mathrm{mg} / \mathrm{kg}$ ketamine hydrochloride, i.p. $10 \mathrm{mg} / \mathrm{kg}$ xylazine and brain tissues were obtained. Brain tissues were washed with saline and after removing excessive water they were kept in deep freezer $\left(-80^{\circ} \mathrm{C}\right)$ until analysis. Tissue sections were obtained in $10 \%$ formaldehyde prepared for histopathological analysis.

\section{Preparation of Tissue Extract and Biochemical} Assays

Tissue extract was preparationed according to method used by Xia (Xia et al., 1994). MDA levels was done according to method used by Okhava (Ohkava et al.,1979). GSH concentration was measured according to Tietz (Tietz,1969) and Fairbans et al., (1999). SOD enzyme activity is detect according to modified method by Sun et al.(Sun et al.,1988). The total protein concentration in the tissue homogenate was according to Lowry (1951).

\section{Histopathological Analysis of The Brain}

After treatment, eight rats in each group were anaesthetized with $60 \mathrm{mg} / \mathrm{kg}$ ketamine i.p.10 mg/ $\mathrm{kg}$ Xylazine, euthanized by decapitation under deep anesthesia and necropsied. After that the cerebrum were taken out and isolated immediately. Also, brain tissue samples were fixed in $10 \%$ neutral-buffered formalin for $48 \mathrm{~h}$. The tissue samples were processed as routine protocol of dehydrated with alcohol series (50 $\%, 70 \%, 96 \%$ and $100 \%$ ) cleared in xylene and then embedded in paraffin. And then paraffin embedded tissue samples sectioned at $5 \mu \mathrm{m}$ thickness by rotary microtome (Leica, RM2125)(Anderson et al., 2002). The slides were stained with hematoxylin and eosin for histological examination (Lilli, 2008). Finally the slides were examined and photographed by using light microscope with imaging system (Leica,DM2500/ DFC295).

\section{Statistical Analysis}

Results of statistical analysis regarding biochemical values (MDA,GSH,SOD) are presented as $\mathrm{X} \pm \mathrm{SEM}$. Statistical significance of difference between means was evaluated with one-way Analysis of variance. Analysis of data was performed with SPSS for Windows version 11.5. 


\section{RESULTS AND DISCUSSION}

Brain MDA levels show that increase in $\mathrm{Cd}$ administered group $(\mathrm{p}<0.01)$ as well as increase in $\mathrm{Cd}+$ AST administered group $(\mathrm{p}<0.05)$ was found significant compared to control. In addition decrease in $\mathrm{Cd}+\mathrm{AST}$ groups compared to $\mathrm{Cd}$ groups was also found significant $(\mathrm{p}<0.01)$. GSH levels shows a decrease in $\mathrm{Cd}$ and $\mathrm{Cd}+\mathrm{AST}$ groups match control $(\mathrm{p}<0.05)$. SOD enzyme activity was found significantly lower in cadmium and $\mathrm{Cd}+\mathrm{AST}$ groups match control $(\mathrm{p}<0.01)$. In addition increase of SOD in $\mathrm{Cd}+\mathrm{AST}$ groups match Cd groups was also found significant $(\mathrm{p}<0.05)$ (Table 1).

Table 1.Results of MDA, GSH levels and SOD enzyme activity

\begin{tabular}{|l|c|c|c|}
\hline \multicolumn{1}{|c|}{ Groups } & MDA(nmol/mg protein) & GSH( $\boldsymbol{\mu m o l} / \mathbf{m g}$ protein) & SOD(IU/ mg protein) \\
\hline Cont & $3.45 \pm 0.13^{*, \#}$ & $4.96 \pm 0.12^{\#, \# \#}$ & $8.04 \pm 0.63^{*, * *}$ \\
\hline Cd & $8.15 \pm 0.60^{*, * *}$ & $1.18 \pm 0.04^{\#}$ & $5.06 \pm 0.38^{*, \#}$ \\
\hline AST & $3.80 \pm 0.16$ & $3.88 \pm 0.19$ & $7.56 \pm 0.74$ \\
\hline Cd + AST & $6.20 \pm 0.90^{\#, * *}$ & $2.85 \pm 0.20^{\# \#}$ & $6.79 \pm 0.59^{*, *,}$ \\
\hline
\end{tabular}

Values are expressed as mean \pm S.E.M *,** $\mathrm{p}<0,01, \#, * \# p<0,05$

In control groups, no significant histopathological differences were noted and the cerebral cortex and hippocampus of the brain tissues were in normal histological structure (Figure $1-\mathrm{A}, \mathrm{E}$ ). In the $\mathrm{Cd}$ (Cadmium) administered group in brain, perineural vacuolation, neuronophagia, severe congestion of blood vessels and satellitosis were found most frequently in cerebral cortex (Figure 1-B) and severe pyramidal neuron loss was observed in the hippocampus (Figure 1-F). Common lesion in the cerebral cortex are as follows; necrosis of some of pyramidal neurons with pyknotic nuclei, neuronal shrinkage and mild microgliosis (Figure 1-B). Mild congestion of blood vessels, slightly neuronal shrinkage and mild microgliosis findings were observed in the $\mathrm{Cd}+\mathrm{AST}$ administered group in cerebral cortex of brain tissues (Figure 1-C). It is also identified that there was mild pyramidal neuron loss in the hippocampus (Figure 1-G). In addition, no significant histopathological evidences are observed in AST in cerebral cortex and hippocampus in the section of rat brain, which is similar to control groups (Figure 1-D, H).

Control groups (Group-1), normal histological structure of cerebral cortex (A), and hippocampus (star) (E). Cd administered group (Groups-2), perineural vacuolation, neuronophagia, satellitosis, and neuronal shrinkage (arrow heads); severe congestion of blood vessels (arrows) in cerebral cortex (B), and severe pyramidal neuron loss (star) in hippocampus (F). Cd + AST administered group (Groups-3), slightly neuronal shrinkage and mild microgliosis (arrow heads); mild congestion of blood vessel (arrow) in cerebral cortex (C), and mild pyramidal neuron loss (star) in hippocampus (G). AST administered groups (Groups-4), normal histological structure of cerebral cortex (D), and hippocampus (star) (H). 


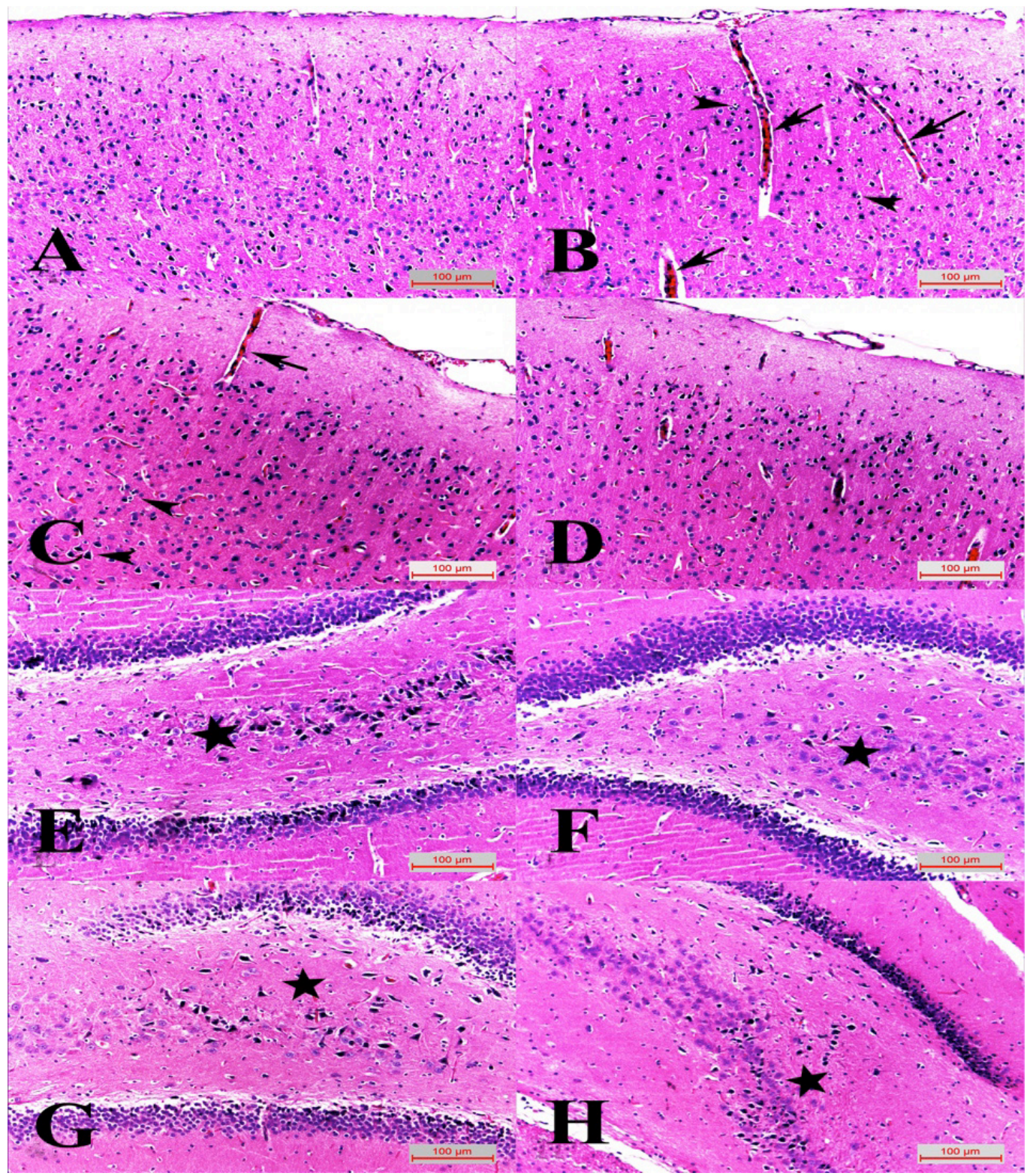

Figure 1. Histopathology of cortex and hippocampus of brain tissues; magnification x10, H\&E staining

AST is a xanthophyll carotene which is found in certain microorganisms and algae and sea animals mainly crustaceans (Choi et al.,2011). It has antioxidant, anti-inflammatory, anticancer and immune modulatory properties (Zhang et al.,2014). One of the biggest heavy metal effects is oxidative stress (Görka et al., 2015). Oxidative stress can be explained as the alterations due to irrationality between oxidant and antioxidant agents found in cell. Free oxygen radicals in cells increase with presence of oxidative stress (Evans, 1993). Cd which is a heavy metal, is found in soil, air and water. It is a member of IIb in periodical table (Stoeppler et al., 1991). It is known that Cd which is a highly toxic environmental pollutant causes generation of ROS such as hydroxyl radical, superoxide anions, nitricoxide and hydrogen peroxide (Stohs et al.,2001). Tissue detriment caused by generation of ROS may trigger some defense mechanisms. Initial defense mechanism contain antioxidants such as SOD and GSH (Cetin et al.,2001; Gürlek et al.,2006). GSH and SOD which are among the most significant antioxidants against free radicals prevent lipid peroxidation (Seyhan and Canseven., 2006; Suzer et al., 2000). In this study lipid peroxidation was done with MDA which arises after 
detriment of lipid structures found in cell membranes. In our study brain MDA level rise_significantly in $\mathrm{Cd}$ group compared to control as expected. In this experimental setup AST administration decreased MDA level which is evident $\mathrm{Cd}+\mathrm{AST}$ group compared to $\mathrm{Cd}$ group. In a study oxidative stress triggered with $\mathrm{Cd}$, protective role of $\alpha$-tocopherol blood, liver and brain tissue was investigated. They found an rise in brain MDA level in Cd group compared to control whereas a reduce in $\mathrm{Cd}+\alpha$-tocopherol group compared to $\mathrm{Cd}$ group (Nemmiche et al., 2007). In another study, brain damage caused by $\mathrm{Cd}$ was tried to be alleviated with ferulic acid. They found a significantly increase in MDA levels in Cd group compared to control (Adefegha et al., 2016). Rise in MDA level is an indicator of augmented lipid peroxidation and oxidative stress. Our findings are in parallel with results of other studies in this subject. GSH levels shows a decrease in Cd group compared to control and an amelioration in $\mathrm{Cd}+\mathrm{AST}$ group compared to Cd group. In a study protective impact of melatonin on neurotoxicity and oxidative stress induced by $\mathrm{Cd}$ was evaluated. GSH level was found lower in $\mathrm{Cd}$ compared to control and an amelioration of this level in $\mathrm{Cd}+$ melatonin group was found (Shagirtha et al., 2011). In another study investigating oxidative stress by $\mathrm{Cd}$ in rat brain and testis tissue and protective effect of b-carotene, GSH levels were found lower in Cd group (El-Missiry and Shalaby, 2000). SOD enzyme activity was attenuated in $\mathrm{Cd}$ and $\mathrm{Cd}+\mathrm{AST}$ groups compared to control significantly. In addition SOD level rise significantly in $\mathrm{Cd}+\mathrm{AST}$ groups compared to cadmium administrated group significantly.

For GSH and SOD parameters our results are in accordance with existing literature. Experimental studies in the central nervous system of newborn rats and rabbits subject to high doses of $\mathrm{Cd}$, have shown several hemorrhages in the cerebral cortex, pyramidal cells with neuroglial cells with cytolysis (Gabbiani et al., 1967). It has been found in a study that central nervous system detriment in newborn rats generation by low doses of cadmium; brain cortex, cerebellum showed extensive necrosis and hemorrhage (Wong and Klaassen, 1982). It is reported that in the necrotic areas of the brain cortex (pyknosis and interstitial edema), slightly damaged vascular endothelium in cerebral cortex were shown after cadmium administration (Mendez et al., 2001; Mendez and Rios, 2007). Yoshida (Yoshida, 2001) has indicated that implement of $\mathrm{Cd}$ primarily impact the integrity and permeability of the vascular endothelium and necrotic vary in nerve cells occur secondarily to this impact. It is reported that, $\mathrm{Cd}$ can rise permeability of the blood brain barrier in rats (Shuka and Chandra, 1987) penetrate and collect in the brain of improve and grown rats (Mendez and Rios, 2007; Goncalves et al., 2010) leading to brain intracellular collection, cellular dysfunction and cerebral edema. One report of a 2-year-old, boy with abruptly death exhibition the exist of $\mathrm{Cd}$ and histological proof of distinct cerebral edema with perivascular protein infiltrate, indicating blood-brain barrier disruption (Provias et al., 1994). It has been shown that histopathologically, the structure in the cortex was obviously disorganized and $\mathrm{Cd}$ may have caused brain detriment, and the cellular distribution across cortex, and infarction in hippocampus caused the abnormal appearance in mice (Chen et al., 2014). In our study, in the Cd administered group in brain, perineural vacuolation, neuronophagia, severe congestion of blood vessels and satellitosis were found most frequently in cerebral cortex (Figure1-B) and severe pyramidal neuron loss was observed in the hippocampus (Figure1-F). Common lesion in the cerebral cortex are as the following; necrosis of some of pyramidal neurons with pyknotic nuclei, neuronal shrinkage and mild microgliosis (Figure1-B). These findings are similar to most of $\mathrm{Cd}$ neurotoxicity studies. AST can be transported by fat molecules directly to the organs and tissues most needed, such as the brain. (Higuera et al., 2006). In experimental models of neurological disorders, AST-mediated neuroprotection contain anti-oxidative, anti-inflammatory and antiapoptotic mechanisms. (Shen et al.,2009; Yamagishi et al.,2014). Itis also showed that AST improve cell and mitochondrial membrane stability. This study propose that AST may have preventive impression on neurodegenerative diseases, addicted its antioxidant potential and mitochondria preventive, and might be a promising neuroprotective medicinal agent for oxidative stress-related neurodegenerations (Chan et al., 2009; Ikeda et al., 2008; Liu et al., 2009). In our experiment, mild congestion of blood vessels, 
slightly neuronal shrinkage and mild microgliosis are the findings that were observed in the Cd+AST administered group in cerebral cortex of brain tissues (Figure1-C). It is also identified that there was mild pyramidal neuron loss in the hippocampus (Figure1-G). In our study, difference observed in histopathological findings in the cerebral cortex and hippocampus with the aid of microscopic examination shows that in the control and AST administered groups, no microscopic findings were recognize, in the brain, while severe lesions were seen in the $\mathrm{Cd}$ administered group and only mild degenerative lesions were seen in the $\mathrm{Cd}+\mathrm{AST}$ group.

\section{REFERENCES}

Adefegha SA, Omojokun OS, Oboh G, Fasakin O, Ogunsuyi O, 2016. Modulatory effects of ferulic acid on cadmium-induced brain damage. Journal of evidence-based complementary \& alternative medicine, 21: 56-61.

Alaee S, Talaiekhozani A, Rezaei S, Alaee K, Yousefian E, 2014. Cadmium and male infertility. Journal of Infertility and Reproductive Biology, 2:62-69.

Amara S, Douki T, Garrel C, Favier A, Ben Rhouma K, Sakly M, Abdelmelek H, 2011. Effects of static magnetic field and cadmium on oxidative stress and DNA damage in rat cortex brain and hippocampus. Toxicology and industrial health, 27: 99-106.

Anderson G, Bancroft J, 2002. Tissue processing and microtomy, In: Bancroft, John, Gamble, Marilyn (Eds.), Theory and Practice of Histological Techniques. 5th edition, Harcourt Publishers Limited, London: Churchill Livingstone.

Chan KC, Mong MC, Yin MC, 2009. Antioxidative and AntiInflammatory Neuroprotective Effects of Astaxanthin and Canthaxanthin in Nerve Growth Factor Differentiated PC12 Cells. Journal of food science,74: 225-231.

Chen S, Ren Q, Zhang J, Ye Y, Zhang Z, Xu Y, Gao W, 2014. Nacetyl-L-cysteine protects against cadmium-induced neuronal apoptosis by inhibiting ROS-dependent activation of Akt/ mTOR pathway in mouse brain. Neuropathology and applied neurobiology, 40: 759-777.

Choi HD, Kang HE, Yang SH, Lee MG, Shin WG, 2011. Pharmacokinetics and first-pass metabolism of astaxanthin in rats. British Journal of Nutrition, 105: 220-227.

Ciesielski T, Weuve J, Bellinger DC, Schwartz J, Lanphear B, Wright RO, 2012. Cadmium exposure and neurodevelopmental outcomes in US children. Environmental health perspectives, 120: 758 .

Çetin C, Kose AA, Aral E, 2001. Protective effect of fucoidin (a neutrophil rolling inhibitor) on ischemia reperfusion injury: experimental study in rat epigastric island flaps. Ann Plast Surg, 47: 540

\section{CONCLUSION}

As a result elevated MDA level due to $\mathrm{Cd}$ administration was attenuated with AST administration. Decreased GSH level and SOD enzyme activity due to $\mathrm{Cd}$ administration was increased with AST administration. In addition, AST administration decreased histopathological lesions. Consequently, it is thought that AST may be used for protection against brain oxidative damage due to $\mathrm{Cd}$.

El-Missiry MA, Shalaby F, 2000. Role of $\beta$-carotene in ameliorating the cadmium-induced oxidative stress in rat brain and testis. Journal of biochemical and molecular toxicology,14: 238-243.

Evans PH, 1993. Free radicals in brain metabolism and pathology. British Medical Bulletin, 49: 577-587.

Fairbans VF, Klee GG, 1999. Biochemical aspects of hematology. İn: CoA.Burtis and E.R.Ashwood, Editors, Tietz Textbook of clinical Chemistry,Sounders, Philadelphia, 1991-2106.

Fowler BA, 2009. Monitoring of human populations for early markers of cadmium toxicity: a review. Toxicology and applied pharmacology, 238: 294-300.

Gabbiani G, Baic D, Deziel C, 1967. Toxicity of cadmium for the central nervous system. Experimental neurology,18: 154-160.

Gonçalves JF, Fiorenza AM, Spanevello RM, Mazzanti CM, Bochi GV, Antes FG, Schetinger MRC, 2010. N-acetylcysteine prevents memory deficits, the decrease in acetylcholinesterase activity and oxidative stress in rats exposed to cadmium. Chemico-biological interactions, 186: 53-604.

Górka IM, Januszewska L, Michalak A, Prokopowicz A , Januszewska E, Pawlas N, Pawlas K, 2015. Effects of chronic exposure to lead, cadmium, and manganese mixtures on oxidative stress in rat liver and heart. Arh Hig Rada Toksikol, 66: $51-62$

Gurlek A, Celik M, Parlakpinar H, 2006. The protective effect of melatonin on ischemia-reperfusion injury in the groin (inferior epigastric) flap model in rats. J Pineal Res, 40: 312

Hart RP, Rose CS, Hamer R.M, 1989. Neuropsychological effects of occupational exposure to cadmium. Journal of clinical and experimental neuropsychology, 11: 933-943.

Higuera-Ciapara I, Felix-Valenzuela L, Goycoolea FM, 2006. Astaxanthin: a review of its chemistry and applications. Critical reviews in food science and nutrition, 46: 185-196.

Hwang YH, Hong SG, Mun SK, Kim SJ, Lee SJ, Kim JJ, Yee ST, 2017. The Protective Effects of Astaxanthin on the OVAInduced Asthma Mice Model. Molecules, 22, 2019. 
Ikeda Y, Tsuji S, Satoh A, Ishikura M, Shirasawa T, Shimizu T, 2008. Protective effects of astaxanthin on 6-hydroxydopamineinduced apoptosis in human neuroblastoma SH-SY5Y cells. Journal of neurochemistry, 107: 1730-1740.

Karoui-Kharrat D, Kaddour H, Hamdi Y, Mokni M, Amri M, Mezghani S, 2017. Response of antioxidant enzymes to cadmium-induced cytotoxicity in rat cerebellar granule neurons. Open Life Sciences, 12: 113-119.

Lilli RD, 2008. The Hematoxylin and Eosin, In: Gamble, Marilyn, Histopathologic Technique and Practical Biochemistry. 8th edition, Elsevier Limited, London: Churchil Livingstone.

Liu X, Shibata T, Hisaka S, Osawa T, 2009. Astaxanthin inhibits reactive oxygen species-mediated cellular toxicity in dopaminergic SH-SY5Y cells via mitochondria-targeted protective mechanism. Brain research, 1254: 18-27.

Lowry OH, Rosebrough NJ, Farr AL, Randall RJ, 1951. Protein Measurement With the Folin Phenol Reagent. The Journal of Biological Chemistry, 265-275.

Mendez-Armenta M, Barroso-Moguel R, Villeda-Hernández J, Nava-Ruız C, Rios C, 2001. Histopathological alterations in the brain regions of rats after perinatal combined treatment with cadmium and dexamethasone. Toxicology,161: 189-199.

Méndez-Armenta M, Ríos C, 2007. Cadmium neurotoxicity. Environmental Toxicology and Pharmacology, 23: 350-358.

Nemmiche S, Chabane-Sari D, Guiraud P, 2007. Role of $\alpha$-tocopherol in cadmium-induced oxidative stress in Wistar rat's blood, liver and brain. Chemico-biological interactions, 170: 221-230.

Ohkawa H, Ohishi N, Yag1 K, 1979. Assay for Lipid Peroxides in Animal Tissues by Thiobarbituric Acid Reaction. Analytical Biochemistry, 95: 351-358.

Otton R, Marin DP, Bolin AP, Santos, RD, Polotow TG, Sampaio SC, Barros MP, 2010. Astaxanthin ameliorates the redox imbalance in lymphocytes of experimental diabetic rats. Chemico-biological interaction, 186: 306-315.

Provias JP, Ackerley CA, Smith C, Becker LE, 1994. Cadmium encephalopathy: a report with elemental analysis and pathological findings. Acta neuropathologica, 88: 583-586.

Satarug S, Garrett SH, Sens MA, Sens DA, 2010. Cadmium environmental exposure and health outcomes. Environ Health Perspect, 118: 182-190.

Seyhan N, Canseven AG, 2006. In vivo effects of ELF MFs on collagen synthesis, free radical processes, natural antioxidant system, respiratory burst system, immune system activities, and electrolytes in the skin, plasma, spleen, lung, kidney, and brain tissues. Electromagn Biol. Med 25: 291-305

Shagirtha K, Bashir N, Milton Prabu S, 2016. Neuroprotective efficacy of hesperetin against cadmium induced oxidative stress in the brain of rats. Toxicology and industrial health, 33: 454-468.

Shagirtha K, Muthumani M, Prabu SM, 2011. Melatonin abrogates cadmium induced oxidative stress related neurotoxicity in rats. Eur Rev Med Pharmacol Sci, 15: 1039-1050.

Shen H, Kuo CC, Chou J, Delvolve A, Jackson SN, Post, J, Harvey $\mathrm{BK}, 2009$. Astaxanthin reduces ischemic brain injury in adult rats. The FASEB, 23: 1958-1968.

Singh N, Rani P, Gupta M, Goel N ,Tandan N, 2013. Effects of aqueous extract of Camellia sinensis (1.) O. kuntze on liver markers of cadmium treated rats. Journal of Biotechnology and Pharmaceutical Research, 4: 89-93.
Shukla GS, Chandra SV, 1987. Concurrent exposure to lead, manganese, and cadmium and their distribution to various brain regions, liver, kidney, and testis of growing rats. Archives of environmental contamination and toxicology, 16: 303-310.

Stoeppler M, 1991. Cadmium. In: Merian, E. (Ed.), Metals and their Compounds in the Environment. VCH, Weinheim, NewYork, Basel, Cambridge.

Stohs SJ, Bagchi D, Hassoun E, Bagchi M, 2001. Oxidative mechanisms in the toxicity of chromium and cadmium ions. Journal Environ.Pathol.Toxicol.Oncol, 20: 77-88.

Sun Yi, Oberley LW, Ying Li, 1988. A simple method for clinical assay of superoxide dismutase. Clinical Chemistry, 3413: 497 500 .

Suzer T, Coskun E, Demir S, 2000. Lipid peroxidation and glutathione levels after cortical injection of ferric chloride in rats: effect of trimetazidine and deferoxamine. Res. Exp. Med, 199: 223-229

Szkup-Jablonska M, Karakiewicz B, Grochans E, Jurczak A, Nowak-Staz G, Rotter I, Prokopowicz A, 2012. Effects of blood lead and cadmium levels on the functioning of children with behaviour disorders in the family environment. Annals of Agricultural and Environmental Medicine, 19: 241-246.

Xia E, Rao G, Remmen HV, Heydari A, Richardson A, 1994. Activites of Antioxidant Enzymes in Various Tissues of Male Fischer 344 Rats Are Altered by Food Restriction. Biochemical and Molecular Roles of Nutrients, 125: 195-201.

Tietz F, 1969. Enzymatic method for quantitative determination of nanogram amounts of total and oxidized glutathione: Applications to mammalian blood and other tissues. Analytical Biochemistry, 27: 502-522.

Wong KL, Klaassen CD, 1982. Neurotoxic effects of cadmium in young rats. Toxicology and applied pharmacology, 63: 330337.

Wu S, Li S, Xu XR, Deng GF, Li F, Zhou J, Li HB, 2012. Sources and bioactivities of astaxanthin. Int. J. Mod. Biol. Med, 1: 96107.

Yadav R, Archana J, Goyal PK, 2010. Protective action of diltiazem against cadmium induced biochemical changes in the brain of Swiss albino mice. Annals of neurosciences, 12: 37-40.

Yamagishi R, Aihara M, 2014. Neuroprotective effect of astaxanthin against rat retinal ganglion cell death under various stresses that induce apoptosis and necrosis. Molecular vision, 20: 1796.

Yoshida S, 2001. Re-evaluation of acute neurotoxic effects of $\mathrm{Cd}$ ${ }^{2}+$ on mesencephalic trigeminal neurons of the adult rat. Brain research, 892: 102-110.

Zhang XS, Zhang X, Zhou ML, Zhou XM, Li N, Li W, Shi JX, 2014. Amelioration of oxidative stress and protection against early brain injury by astaxanthin after experimental subarachnoid hemorrhage. Journal of neurosurgery, 121: 42-54.

Zuluaga M, Barzegari A, Letourneur D, Gueguen V, Pavon-Djavid G, 2017. Oxidative Stress Regulation on Endothelial Cells by Hydrophilic Astaxanthin Complex: Chemical, Biological, and Molecular Antioxidant Activity Evaluation. Oxidative Medicine and Cellular Longevity, Article ID 8073798. 